\title{
Proses Komunikasi Interpersonal dalam Membangun Relasi Pasangan Beda Agama GN dan DN
}

\section{Interpersonal Communication Process in Building Relationships of Interfaith Couples GN and DN}

\author{
Riko Aji Pratama \\ Universitas Atma Jaya Yogyakarta \\ Jl Babarsari No. 6S Sleman, Yogyakarta, Indonesia \\ Email : rikoajipr@gmail.com
}

Received : January 1, 2021 ; Revised: June 10, 2021; Accepted: August 15, 2021

\begin{abstract}
Couples of different religions are prone to conflicts related to issues, especially regarding beliefs. In interfaith marriages, the inner bond that exists between a man and a woman but of different religions gives rise to state and religious administrative obstacles as well as other non-administrative obstacles. The purpose of this study was to determine the communication process in building relationships between interfaith couples. This study uses interpersonal communication theory and social penetration theory. This research using qualitative descriptive methods and interviews to collect data. The data obtained is the result of in-depth interviews with 2 sources who have become husband and wife of different religions. The research process from data reduction, data presentation, then analyzed to draw conclusions. The results of this study explain that through the process intimate relations. Interpersonal communication processes that are intertwined become a means to build better and harmonious relationships. The process is influenced by the memory of each partner. In building relationships through interpersonal communication there are factors that influence relationships, such as two-way communication, openness, comfort, trust, and supportiveness is a way of maintaining relationships
\end{abstract}

Keywords: Communication Process; Different religion; Interpersonal Communication; Interfaith Couples

\begin{abstract}
Abstrak
Penelitian ini membahas tentang proses komunikasi dalam membangun relasi pasangan beda agama. Pasangan beda agama rentan adanya konflik yang berhubungan dengan permasalahan khususnya menyangkut keyakinan. Dalam perkawinan beda agama, ikatan batin yang terjalin antara seorang pria dan wanita tetapi berbeda agama sehingga memunculkan kendala administratif negara dan agama serta kendala non administratif lainnya. Tujuan penelitian ini adalah untuk mengetahui proses komunikasi dalam membangun relasi pasangan beda agama. Penelitian ini menggunakan teori komunikasi interpersonal, proses komunikasi dari pengenalan sampai dengan yang lebih intim pemetaan dari pengertian teori penetrasi sosial. Penelitian ini merupakan penelitian kualitatif dengan menggunakan metode deskriptif kualitatif dan wawancara untuk mengumpulkan data. Data yang diperoleh merupakan hasil wawancara mendalam dengan 2 narasumber yang telah menjadi suami istri yang berbeda agama. Proses penelitian dari
\end{abstract}


reduksi data, penyajian data, kemudian dianalisis untuk pengambilan kesimpulan. Hasil Penelitian ini menjelaskan bahwa melalui proses dari intim menuju ke lebih intim. Proses komunikasi interpersonal yang terjalin menjadi sarana untuk membangun relasi yang lebih baik dan harmonis. Proses komunikasi membangun relasi tidak semata-mata langsung dekat ada proses didalamnya. Proses tersebut dipengaruhi oleh memori dari masing-masing pasangan. Penelitian sebelumnya menjelaskan mengenai kecerdasan dalam berkomunikasi dalam perbedaan agama antar pegawai dalam suatu instansi untuk mengetahui strategi dalam berkomunikasi. Dalam membangun relasi melalui komunikasi interpersonal ada faktor-faktor yang memengaruhi relasi seperti komunikasi dua arah, keterbukaan, kenyamanan, sikap percaya, suportif dan mendukung adalah cara dalam pemeliharaan hubungan

Kata Kunci: Beda Agama; Komunikasi Interpersonal; Pasangan Suami Istri; Proses Komunikasi

\section{Pendahuluan}

Pada pasangan beda agama rentan adanya konflik yang berhubungan dengan permasalahan khususnya menyangkut keyakinan, dalam perkawinan beda agama adalah ikatan batin yang terjalin antara seorang pria dan wanita tetapi berbeda agama sehingga menyebabkan tersangkutnya dua peraturan yang berbeda mengenai syarat-syarat dan tata cara perkawinan dalam perlaksanaan perkawinan sesuai hukum masingmasing agama untuk membentuk keluarga bahagia kekal berdasarkan Ketuhanan Yang Maha Esa (Rusli \& Tama, 1986). Perbedaan tersebut dapat menjadi konflik dalam suatu relasi sehingga memerlukan komunikasi sebagai sarana untuk menemukan solusinya.

Hubungan yang tidak direstui orang tua juga merupakan konflik yang dapat memengaruhi hubungan itu sendiri. Faktor dapat ditemukan dari orang itu sendiri, pasangan, atau orang tua dari kedua belah pihak, perbedaan agama, suku, domisili, masa lalu orang tua dan masalah adat seperti yang dialami oleh Hana Eliza perempuan berusia 32 tahun, Hana sejak remaja diwanti-wanti oleh orang tuanya agar tidak menjalin asmara dengan lelaki yang berbeda agama dan suku namun Hana jatuh hati dengan pria yang memiliki latar belakang agama dan suku yang berbeda. Namun pada akhirnya hubungan tersebut tidak direstui oleh orang tuanya, dan yang direstui hanya yang sekarang menjadi suami Hana yang seagama dan orang Jawa (Primastika. 2018).

Komunikasi dalam kehidupan sehari-hari berfungsi untuk membangun atau membuat pesan dalam berinteraksi demi meningkatan ikatan secara personal. Komunikasi menjadi titik awal dalam kehidupan manusia untuk menjalin relasi, Menurut Joseph A. DeVito dalam Winarso (2005:5) mengatakan bahwa komunikasi adalah proses yang terjadi antara dua orang yang saling mengirim dan menerima pesan secara langsung memberikan timbal balik.

Manusia sebagai mahkluk sosial perlu berhubungan dengan orang lain. Setiap orang memerlukan adanya ketertarikan secara emosional dengan orang lain untuk dapat 
terhubung. Hubungan yang mengakui adanya keberadaan orang lain, memberikan kasih sayang satu dengan yang lainya kepada lawan jenis dalam kehidupan remaja sering disebut dengan sepasang kekasih. Dalam prosesnya maka dapat dikatakan bahwa komunikasi adalah proses dalam menyamakan pikiran, persepsi rasa antara komunikator dengan komunikan (Mulyana, 2005:14). Dalam hubungan ini dapat dikatakan bahwa interaksi yang dilakukan semakin mendalam dan keterbukaan antar individu sangat diutamakan.

Menurut Mulyana dalam Suranto (2011: 3) komunikasi antarpribadi adalah proses komunikasi yang dilakukan secara langsung yang memungkinkan individu - individu memberikan reaksi secara verbal maupun non verbal. Menurut Devito (1989) komunikasi interpersonal adalah proses penyampaian pesan oleh satu orang dan penerima pesan yang lain atau sekelompok kecil yang memberikan dampak dan peluang untuk memberikan umpan balik dalam Effendy (2003: 30).

Komunikasi yang dilakukan oleh lawan jenis dapat menimbulkan perasaan cinta berawal dari interaksi yang terjalin secara berkala dan berangsur lama. Dalam interaksi yang terjalin dalam hubungan dengan lawan jenis ini diakui keberadaannya dimana mereka berbagi keluh kesah yang menganggap pasangan yang peduli dan memahami dirinya dalam (Lukiati 2009: 73).

Pengenalan lebih jauh tentang calon pasangan yang dapat memilki tujuan untuk melangsungkan pernikahan yang diharapkan dapat menjadi pasangan selamanya tanpa memandang latar belakang termasuk perbedaan agama. Dalam hal ini, perbedaan dapat menjadi konflik yang dapat menghambat hubungan tersebut, tentunya konflik yang timbul meningkatkan kemampuan penyelesain konflik dengan pasangan. Konflik tersebut dapat dipengaruhi oleh hubungan itu sendiri, baik secara internal maupun eksternal dalam Papalia, Olds \& Feldman (Lambeth \& Hallet,dkk., 2008) Konflik dapat terjadi secara internal yaitu dalam lingkungan keluarga. Setiap orang memiliki latar belakang dan prinsip - prinsip hidup sesuai dengan tata cara dan hukum agama yang diyakini sehingga perbedaan prinsip, tata cara dan hukum agama yang diyakini oleh masing - masing pasangan dapat menyebabkan konflik.

Konflik Interpersonal dapat dipengaruhi bahwa komunikasi terjadi kegagalan karena adanya persepsi yang berbeda dari setiap individu yang dapat menghalangi tecapainya tujuan yang diinginkan (Hardjana, 1994). Tak jarang dengan adanya konflik dapat mengakibatkan hubungan itu berakhir tidak sesuai yang diharapkan.

Membina dan menjaga sebuah hubungan menjadi suatu hal penting untuk membangun relasi kepada orang lain melalui komunikasi interpersonal. Komunikasi interpersonal terbukti memberikan kontribusi yang efektif dalam prosesnya untuk membuat seseorang merasa lebih baik secara fisik dan psikologis (West \& Turner, 2009: 24). 
Dalam konteks ini peneliti tertarik untuk menganalisis proses membangun relasi pasangan beda agama dengan menggunakan teori penetrasi sosial. Peneliti menggunakan teori penetrasi sosial karena dalam komunikasi terjadi proses perkembangan yang dijelaskan melalui tahapan - tahapan (West and turner, 2008: 200), berawal dari pertanyaan yang mendasar dan berkembang menjadi pertanyaan - pertanyaan yang mengupas lebih dalam, sehingga dalam komunikasi tersebut menemukan titik dimana keintiman diperlihatkan melalui proses dalam tahapan komunikasi. Dimana keintiman disini merupakan topik pembahasan dan pengungkapan diri yang bersifat privasi.

Penelitian sebelumnya adalah Kecerdasan berkomunikasi Dalam Perbedaan Agama (Studi Kasus Pada Pegawai Beragama Kristen dan Pegawai Beragama Islam di FISIPOL Universitas Kristen Indonesia) (Adrian, 2018). Penelitian ini menggunakan teori batasan percakapan, Batasan yang dimaksud adalah tidak menyakiti perasaan si pendengar, meminimalkan penekanan atas pendengar, kejelasan dalam mengusahakan tujuan pokok. Dasar dari pokok permasalahan yang peneliti sebelumnya dijelaskan pada realitas sosial terkait ujaran kebencian terhadap agama yang bisa menyebabkan pertentangan dan konflik.

Penelitian ini dibatasi pada kedalaman komunikasi. Penetitian ini bermaksud untuk mendeskripsikan dan menganalisis strategi komunikasi pegawai pegawai
FISIPOL UKI yang berbeda agama Kristen dan Islam untuk mengatasi berita negatif tentang ujaran kebencian melalui medi. Penelitian ini bertujuan untuk mengetahui strategi komunikasi dalam menghadapi berita negatif, penelitian ini menggunakan metode studi kasus. Hasil penelitian kualitatif ini adalah perbedaan agama bukan menjadi pembatas dengan menggunakan komunikasi yang baik, meliputi saling tegur sapa, bertoleransi, menggunakan kata - kata yang sopan, tidak saling menyinggung agama sesama pegawai.

\section{Kerangka Teori}

Komunikasi yang dilakukan oleh pasangan merupakan komunikasi yang dilakukan oleh dua individu untuk memahami satu dengan yang lainnya. Komunikasi ini merupakan komunikasi interpersonal.

\subsection{Komunikasi Interpersonal}

Menurut Devito dalam Effendy (2003: 30) komunikasi interpersonal adalah proses penyampaian pesan oleh satu orang dan penerima pesan yang lain atau sekelompok kecil yang memberikan dampak dan peluang untuk memberikan umpan balik. Sedangkan menurut Indriyo Gitosudarmo dan Agus Mulyono dalam Suranto (2001:205) menjelaskan bahwa dalam interaksi komunikasi interpersonal merupakan bentuk tatap muka secara langsung yang memberikan komunikasi dua arah baik secara verbal maupun non verbal, dengan memberikan informasi dan perasaan secara emosional dalam interaksi antara individu tersebut ataupun antar individu dalam suatu lingkungan atau kelompok. 
Komunikasi antar pribadi lebih melihat bagaimana kedalaman dalam berkomunikasi terhadap dua orang. Kedalaman dalam berkomunikasi dapat menentukan hubungan relasi yang sudah di bangun dapat terus berlanjut atau bahkan saling menjauh dan cenderung meninggalkan relasi yang sudah dibangun.

Pada komunikasi antar pribadi dalam kedalam berkomunikasi tidak serta merta langsung terjadi komunikasi intim diantara kedua belah pihak. Ada proses didalam komunikasi tersebut. Berdasarkan kedalaman dalam berkomunikasi tersebut dalam hal ini maka menggunakan teori penetrasi sosial untuk memahami pemetaan proses komunikasi dari intim ke yang lebih intim menurut pengertian dari teori penetrasi sosial.

\subsection{Teori Penetrasi Sosial}

Menurut Irwin Altman dan Dalmas Taylor dalam West \& Turner (2008: 196) teori penetrasi sosial adalah proses ikatan hubungan antara individu - individu berawal dari komunikasi umum menuju ke komunikasi yang lebih intim. Dalam konteks ini adalah hubungan dalam pasangan sehingga keintiman disini dapat dilihat secara fisik, intelektual maupun secara emosional sehingga dapat pasangan tersebut dapat melakukan suatu aktivitas yang sama (West \& Turner, 2008: 196).

\section{Metode Penelitian}

Metode yang digunakan adalah metode studi kasus dengan mendeskripsikan semua temuan data dari hasil wawancara mendalam dengan narasumber. Pendekatan yang dilakukan menggunakan pendekatan deskriptif kualitatif dengan upaya menggambarkan suatu gejala sosial dengan meringkas berbagai situasi, kondisi yang timbul dimasyarakat yang menjadi suatu objek penelitian (Bungin, 2013:48).

Penelitian ini tidak menguji data atau memprediksi dan hanya memaparkan situasi dari peristiwa yang terjadi (Rakhmat, 2009:24). Penelitian kualitatif memiliki metode pengumpulan data, analisis dan intepretasi untuk memahami, mengeksplorasi makna yang terjadi dari masalah sosial aau kemanusiaan (Creswell, 2010:4). Tujuan menggnakan sifat penelitian deskriptif karena peneliti ingin mengetahui karakteristik secara individu dari pasangan tersebut.

Dalam Subjek penelitian ini adalah informan yang bersedia untuk diwawancarai oleh peneliti. Karena penelitian ini bersifat pribadi maka untuk kenyamanan bersama informan hanya menggunakan nama inisial GN sebagai pihak pria dengan usia 37 tahun dan DN sebagai pihak wanita 37 tahun. Pasangan ini sebelumnya menjalin hubungan terlebih dahulu selama 2 tahun dan akhirnya memutuskan untuk menikah tahun 2006 dengan latar belakang beda agama Islam (GN) dan Katholik (DN).

Teknik pengumpulan data menggunakan Teknik wawancara mendalam dan lengkap dengan narasumber, pertanyaan tersebut dibuat berdasarkan garis besar dari pokok - pokok yang ditanyakan kemudian dikembangkan supaya peneliti mendapatkan data yang makin mendalam, jika diperlukan wawancara ini diulang - ulang secara intensif agar data yang didapatkan 
semakin mendalam (Kriyantono, 2006:100).

Teknik dalam menganalisis data, pertama reduksi data. Proses pengumpulan data merupakan reduksi data. Dalam proses ini peneliti mendapatkan data melalui dokumen tentang subjek penelitian, obeservasi lapangan, wawancara yang dilakukan kepada subjek penelitian. Dalam prosesnya peneliti melakukan dokumentasi seperti merekam wawancara, kemudian menafsirkan sesuai dengan data yang diperlukan. Dalam proses reduksi data merupakan pengelompokan data yang dapat didiversifikasi untuk dijadikan temuan data dilapangan (Iskandar, 2008:223) Sehingga peneliti melakukan wawancara secara mendalam untuk mengumpulkan data.

Kedua, penyajian data. Penyajian data merupakan pengelompokan data sesuai dengan konteks maupun kategori-kategori dari setiap data yang telah didapatkan. Data yang didapatkan merupakan data mentah yang mungkin tidak semuanya digunakan. Dalam penyajian data peneliti menyusun data agar dapat menjelaskan sesuai dengan masalah yang diteliti. Sehingga dalam penyajian data peneliti tidak langsung menarik kesimpulan dengan cepat (Iskandar, 2008:223).

Ketiga, pengambilan kesimpulan. Analisis lanjut dari penyajian data dan reduksi data adalah pengambilan kesimpulan. Kesimpulan yang dilakukan peneliti bukan berarti menutup kemungkinan untuk mendapatkan masukan. Data yang diterima dapat diuji kembeli melalui merefleksikan kembali temuan data di lapangan, diskusi dengan sejawat untuk mendapatkan kebenaran ilmiah (Iskandar, 2008:224).

\section{Hasil Penelitian dan} Pembahasan

\subsection{Membangun Relasi Komunikasi Interpersonal}

Proses yang terjadi oleh kedua belah pihak pasangan menunjukkan adanya interaksi yang berawal dari pertemuan di tempat penjual pom mini. Proses interaksi ini merupakan interaksi secara primer.

Interaksi primer akan berkelanjutan setelah kedua belah pihak memahami pesan yang diberikan satu dengan yang lainnya. Setelah pesan dan keinginan kedua belah pihak tercapai untuk membangun relasi. Proses interaksi semakin mendalam dalam bentuk interaksi secara sekunder melalui media telepon.

Dari awal adanya adaptasi dari kedua belah pihak sudah menunjukkan adanya proses interaksi yang terjadi. Kemudian proses komunikasi berbicara secara langsung oleh kedua belah pihak mulai terjadi setelah sering bertemu. Proses komunikator oleh pihak wanita melalui menyapa yang disampaikan kepada pihak pria sebagai komunikan, kemudian menafsirkan pesan yang diterima dan merespon balik dengan menjawab sapaan. Pada awal disini terlihat pihak wanita melaksanakan keinginannya untuk berkomunikasi berbicara secara langsung kepada pihak pria.

Proses awal interaksi pasangan bermula terjadi saat pertemuan secara berulang karena mereka 
berada pada satu lingkungan tempat tinggal. Pertemuan yang terjadi secara terus menerus menyebabkan keduanya menginginkan adanya komunikasi dan terjadi interaksi secara langsung tatap muka. Pertemuan berawal dari pihak pria sering melihat pihak wanita di tempat pom mini di depan rumah pihak pria.

Menariknya dari temuan data oleh peneliti, mengungkapkan bahwa proses komunikasi dalam membangun relasi pasangan beda agama ada memori yang masih diingat.

Temuan data ini berdasarkan pengalaman dan ingatan. Memori dalam komunikasi interpersonal proses secara terstruktur melalui perekaman, penyimpanan, pemanggilan atau mengingat kembali pengalaman sebelumnya. Memori akan menjadi dasar untuk berperilaku dalam komunikasi interpersonal. Memori atau ingatan dari seseorang bisa menjadi kendala jika memori tersebut pendek atau tidak diingat, begitu juga sebaliknya jika memori itu diingat terus menerus ini dapat menjadi temuan data yang lebih banyak dan menarik.

Dalam hal ini pemetaan proses komunikasi dari pengertian teori penetrasi sosial dalam tahap orientasi. Orientasi adalah tahapan awal yang terjadi didalam teori penetrasi sosial. Pada tahapan ini interaksi yang terjadi hanya pengenalan dengan lawan jenis, keterbukaan yang terjadi hanya sedikit. Adanya tahap orientasi ditunjukan didalam proses awal komunikasi terjadi. Proses awal yang ditunjukan melalui pertemuan dari pasangan di tempat pom mini dan kemudian memulai komunikasi dengan melihat dan menyapa, merupakan tahap awal dari teori penetrasi sosial.

Pada hasil data peneliti mengetahui bahwa interaksi malumalu yang ditunjukan oleh keduanya menunjukkan bahwa proses komunikasi mereka berada ditahap ini, Menyapa, mendengarkan, bercerita dengan penjaga pom, tersenyum dan tertawa menunjukkan keterbukaan yang hanya sedikit untuk mengurangi kesalahpahaman, sikap yang ditunjukan cenderung hati-hati.

Pihak wanita menyadari adanya ketertarikan yang ditunjukkan oleh pihak pria dilihat dari bentuk komunikasi melalui SMS yang dilakukan pihak wanita yang awalnya hendak menghubungi adik pihak pria tetapi direspon oleh pihak pria secara langsung melalui SMS. Berbalas pesan yang dilakukan keduanya disadari pihak wanita sebagai bentuk ketertarikan terhadap dirinya. Hal ini merupakan bentuk interaksi yang terjadi awal mula keduanya menginginkan ada relasi diantara keduanya.

Kegiatan mengobrol diantara keduanya semakin intens. Proses komunikasi sekunder mulai terjalin dengan adanya kegiatan telepon setiap malam melalui telepon rumah. Respon satu dengan yang lainnya ditunjukan diantara keduanya dalam bentuk berbalas telepon setiap malam selama berjam-jam, menunjukkan adanya relasi yang mulai terbangun dan semakin terjalin.

Bentuk tindakan usaha pihak wanita dalam membangun relasi adanya proses adaptasi atas rasa 
malu yang dirasakan dengan mengajak pihak ketiga dalam berkunjung kerumah pihak pria. Proses semakin mengalami peningkatan setelah lama-kelamaan bersedia untuk berkunjung sendiri. lama kelamaan keduanya melakukan interaksi lebih dalam dengan melakukan kegiaatan bersama seperti makan bersama, keluar bersama hanya sekedar untuk menghabiskan waktu bersama. Tindakan keduanya merupakan bentuk keinginan untuk menjalin relasi yang lebih dalam.

Membangun relasi yang ditunjukan oleh pasangan dalam bentuk melakukan kegiatan bersama menunjukan adanya keinginan untuk membangun relasi diantara keduanya. Perkenalan dengan keluarga pihak pria menunjukan adanya tindakan untuk mengenal lebih jauh dalam proses membangun relasi. Relasi tersebut tidak terjadi ketika hanya salah satu pihak yang menginginkan dan tidak ada respon yang ditunjukan oleh pihak yang lainnya.

Interaksi tersebut dalam pemetaan menurut pengertian dari teori penetrasi sosial memasuki tahap pertukaran penjajakan afektif. Dalam temuan data oleh peneliti memaparkan bahwa pasangan mulai memperdalam relasi dengan kegiatan mengobrol semakin intens. Melakukan kegiatan bersama hanya sekedar menghabiskan waktu bersama dan sering berpergian bersama keluarga pria, menurut pemetaan dari pengertian teori penetrasi sosial interaksi tersebut berada dalam tahap pertukaran penjajakan afektif. Keterbukaan dalam meluangkan waktu untuk melakukan kegiatan bersama semakin intens, sehingga pemetaan dari pengertian teori penetrasi sosial pasangan berada pada tahap pertukaran penjajakan afektif yaitu dalam tahap pengenalan lebih lanjut dan keterbukaan semakin ditunjukkan.

\subsection{Faktor-faktor yang Mempengaruhi Komunikasi Interpersonal pada Pasangan Beda Agama}

Dalam proses komunikasi interpersonal, komunikasi yang terjadi dapat meluas dan mendalam karena adanya pengaruh dari faktorfaktor yang terdapat didalam proses komunikasi tersebut. Faktor-faktor tersebut dapat memberikan efek negatif maupun positif dalam komunikasi interpersonal yang terjadi.

Pada hasil data peneliti mengetahui adanya faktor-faktor yang memengaruhi proses berkomunikasi. Faktor-faktor yang ditemukan menunjukan kecenderungan faktor yang lebih dialami oleh pihak wanita sedangkan pihak pria cenderung acuh dan tidak terlalu mempermasalahkan faktorfator yang dapat memengaruhi komunikasi.

Peneliti mengetahui adanya faktor kesan pertama yang membuat perilaku pihak wanita berbeda. Secara teori kesan saat bertemu dapat memengaruhi komunikasi interpersonal. Perbedaan perilaku menunjukkan adanya usaha dalam memastikan persepsi yang timbul dalam membangun relasi pasangan beda agama. Dengan cara mengenal lebih jauh tentang pihak pria, semakin sering bertemu dan keluar bersama untuk mengetahui karakter 
pihak pria secara lebih dalam proses ini juga merupakan pemetaan dari pengertian teori penetrasi sosial dalam tahap pertukaran penjajakan afektif

Dalam tahap ini adalah tahap pengenalan lebih lanjut terhadap lawan bicara terjadi. Keterbukaan satu sama lain yang muncul menunjukan bahwa penetrasi sosial sudah memasuki tahapan ini. Kecenderungan untuk terbuka lebih mendalam ditunjukan dalam tahap ini.

Hasil data menunjukan bahwa peneliti menemukan pengenalan lebih lanjut untuk menjawab keraguan atas persepsi yang dialami pihak wanita. Pengenalan lebih lanjut menunjukan pasangan memasuki pada tahap ini untuk penetrasi sosial yang dilakukan dalam membangun relasi.

Hal itu menunjukan bahwa ada faktor yang memengaruhi komunikasi interpersonal yang terjadi dalam membangun relasi. Tetapi pengaruh tersebut tidak terlalu berpengaruh besar terhadap hubungan pasangan sebagai alasan untuk semakin menjauh. Dalam komunikasinya peneliti mengetahui adanya faktor yang memengaruhi komunikasi dan relasi hubungan semakin membaik. Bentuk proses dilihat dari pasangan semakin sering mengobrol dan terbuka, semakin sering bertemu untuk menghabiskan waktu bersama.

Peneliti mengetahui keterbukaan atas masalah pribadi yang dialami pihak wanita berserta keluarga mengenai ketidaksetujuan hubungan. Ketidaksetujuan hubungan yang ditemukan awal dari keterbukaan dalam hubungan yang terjalin antara kedua belah pihak atas masalah pribadi yang dialami. Pihak pria merespon dengan menunjukkan pedoman dalam menjalin relasi dari restu yang telah diberikan oleh ayah kandung pihak wanita sehingga haln tersebut disampaikan kepada pihak wanita untuk menguatkan dan memberikan sikap suportif kepada permasalahan pribadi yang dialami pihak wanita.

Sikap mulai membuka diri atas masalah pribadi menunjukan proses komunikasi sedang berada pada tahap pertukaran penjajakan afektif. Keterbukaan yang mulai ditunjukkan satu dengan yang lain, tindakan spontan yang ditunjukan untuk menunjukkan sikap suportif dan empati satu dengan yang lainya menunjukkan bahwa proses komunikasi dalam menjalin relasi berada pada tahap ini.

Faktor yang ditemukan peneliti justru menunjukan ada pengaruh kearah positif dalam komunikasi interpersonal. Pasangan menunjukan adanya faktor-faktor tersebut membuat komunikasi pasangan justru semakin efektif dengan ditunjukannya sikap suportif, empati yang ditunjukan satu dengan yang lainnya. Keduanya saling menguatkan dan meyakinkan satu dengan yang lainnya.

\subsection{Konflik Relasi Komunikasi Interpersonal pada Pasangan Beda Agama}

Mengenai konflik yang terjadi dalam relasi komunikasi interpersonal dalam temuan data yang ditemukan.

Perbedaan keyakinan menjadi konflik yang lebih spesifik dikarenakan pasangan memiliki latar belakang agama yang berbeda. 
Perbedaan agama menjadi konflik dikarenakan adanya perbedaan pendapat dan persepsi diantara dua keluarga. Tidak ada titik temu dalam perbedaan pendapat dan keyakinan.

Peneliti mengetahui data mengenai konflik yang semakin kompleks. Konflik semakin kompleks dikarenakan pihak wanita hamil diluar nikah. Sehingga konflik yang ditemukan berbeda dengan teori.

Dalam hal ini dari konflik yang dialami pasangan, peneliti justru mengetahui adanya proses komunikasi yang makin membaik. Hal ini ditunjukan melalui ekspresi dan respon yang ditunjukan oleh pihak pria melalui komunikasi dengan ibunya untuk memberitahukan hasil lab dengan intonasi suara dan sikap bercanda yang menghibur. Cara pihak pria dalam berkomunikasi dan merspon pesan yang diberikan pihak wanita memiliki karakter tersendiri dari awal interaksi perkenalan. Pihak pria cenderung sedikit menunjukkan keterbukaan melalui komunikasi verbal, pihak pria cenderung menunjukkan komunikasi nonverbal seperti dalam bentuk menggandeng tangan saat berkomunikasi secara langsung untuk menguatkan pihak wanita, memiliki sikap yang menghibur dan berbicara dengan intonasi bercanda agar memberikan kesan kepada pihak wanita untuk kuat dan tidak perlu khawatir atas permasalahan yang dialami dan pihak pria menunjukkan kegembiraan atas kabar yang diberikan.

Dalam hal ini proses encoding yang dilakukan pihak pria dan kemudian decoding yang dilakukan pihak wanita terjadi begitu juga sebaliknya pihak wanita memberikan kabar mengenai kehamilan sebagai proses encoding dan proses decoding oleh pihak pria yang merespon melalui komunikasi nonverbal dan akhirnya saling memberikan umpan balik. Ini merupakan proses komunikasi yang merekatkan komunikasi diantara keduanya. Konflik yang dialami justru memberikan stimulus dalam berkomunikasi yang dialami, sikap ekspresif, respon suportif dan menguatkan satu dengan yang lainnya semakin ditunjukkan. Proses menjalin relasi dalam menghadapi konflik memberikan dampak positif bagi pasangan.

\section{Proses}

komunikasi interpersonal yang dialami menurut pengertian dari teori penetrasi sosial, proses tersebut berada pada tahap pertukaran afektif. Tahap ini menunjukan adanya pengungkapan jati diri, keterbukaan satu dengan yang lainnya bukan menjadi beban, dalam tahap ini memperlihatkan secara jelas komunikasi yang terjalin dan mengurangi simbol-simbol dalam berkomunikasi.

Pasangan ini menunjukkan dengan komunikasi secara verbal maupun nonverbal. Komunikasi verbal terjadi secara langsung tatap muka mengenai memberitahukan kabar kehamilan yang dialami. Komunikasi nonverbal ditunjukan melalui respon yang ditunjukkan dengan sikap bercanda, nada intonasi bahagia dan menghibur beserta tindakan menggandeng tangan untuk menemani. Ini menunjukan adanya keterbukaan yang semakin jelas dan proses komunikasi yang ditunjukan antara keduanya sudah tidak ada beban. 
$\begin{array}{ccr}\text { Dalam } & \text { tahap ini } & \text { peneliti } \\ \text { mengetahui } & \text { bahwa } & \text { pasangan } \\ \text { menunjukan } & \text { dengan } & \text { proses }\end{array}$ komunikasi yang dilakukan semakin jelas dan terbuka sehingga menimbulkan rasa nyaman seperti yang ditunjukkan bahwa menguatkan hati untuk tidak terlalu memperdulikan orang lain yang tidak menjalankan hubungan, melalui tindakan seperti menjemput saat melakukan ibadah di Gereja. Ini menandakan bahwa ada usaha serius menjalani hubungan dan tidak mempermasalahkan adanya pemilihan terhadap perbedaan agama yang dijalani.

Konflik dialami juga oleh pihak pria, konflik ini cenderung pribadi karena menyangkut atas prinsip pribadi. Hasil data peneliti mengetahui pihak pria mengalami konflik batin. Konflik pribadi terjadi atas perbedaan informasi dengan apa yang diyakini sehingga menimbulkan kebimbangan untuk mengambil keputusan. Konflik semakin spesifik yang terjadi dalam pasangan beda agama dikarenakan ada konflik pribadi yang timbul.

Pada hasil data peneliti mengetahui bahwa kecemburuan dialami oleh kedua belah pihak, pertama kecemburuan diungkapan melalui pertanyaan-pertanyaan untuk memastikan kekhawatiran yang dialami yang dilakukan oleh pihak wanita. Kedua, kecemburuan disampaikan dengan cara komunikasi nonverbal dalam bentuk sikap diam yang dilakukan oleh pihak pria, pihak wanita merespon dengan sikap merayu dan menggoda untuk mengurangi ketegangan dan mencairkan sikap diam yang ditunjukkan oleh pihak pria.
Menurut pengertian teori penetrasi sosial, keterbukaan atas apa yang dirasakan mengenai kecemburuan menunjukkan bahwa proses komunikasi interpersonal yang dialami dalam tahap pertukaran afektif. Pasangan menunjukkan keterbukaan satu dengan yang lainnya, kecenderungan memperlihatkan, keterbukaan muncul dalam proses komunikasi yang ditunjukkan oleh pasangan dalam membangun relasi. Proses ini semakin mendalam dan lenih intim.

\subsection{Pemeliharaan Relasi Komunikasi Interpersonal pada Pasangan Beda Agama}

Mengenai pemeliharaan relasi komunikasi interpersonal. Pemeliharaan relasi komunikasi interpersonal merupakan proses komunikasi sehingga komunikasi tersebut ditunjukkan untuk menjaga dan memelihara hubungan yang sudah terjalin.

Berdasarkan pada kasus yang diteliti oleh peneliti menunjukkan bahwa terdapat cara-cara untuk memelihara relasi. Pertama emotional attachment yang terwujud dari pasangan yang tidak meminta adanya perpindahan agama. Tidak ada paksaan dalam memeluk agama setelah menikah, keduanya memberikan kebebasan atas keyakinan yang dimiliki, menghormati satu dengan yang lainnya dengan menunjukkan ikut berpartisipasi membantu dalam hari raya agama masing-masing.

Kedua kenyamanan yang terwujud dari sikap saling percaya satu sama lain untuk mengatasi kecemasan yang dialami. Pihak pria menunjukkan sikap bahwa percaya 
akan yang dilakukan isteri sebagai bentuk komunikasi atas kenyamanan yang didapat. Pemahaman satu dengan yang lainnya ketika sedang mengalami kondisi terpuruk dalam pekerjaan dan berdampak pada ekonomi pasangan ini, pihak wanita selalu mengambil sikap dengan tidak egois dan memanfaatkan pendapatan yang ada dengan sebaik mungkin. Menunjukkan sikap mengalah dan mempertimbangkan mana yang lebih penting. Pasangan selalu sebisa mungkin menunjukkan dan selalu berusaha meyakinkan satu dengan yang lainnya. Ketiga adanya anak dari pasangan ini terwujud untuk mendahulukan keperluan anak dan keluarga dengan adaptasi secara alami dan tanpa ada paksaan.

Proses komunikasi yang dilakukan cenderung sangat intim dan mendalam. Spontanitas yang dilakukan sering terjadi. Pemetaan dalam proses komunikasi interpersonal menurut pengertian dari teori penetrasi sosial. Proses memasuki tahap pertukaran stabil. Dalam tahap ini adalah tahap paling terakhir dari teori penetrasi sosial. Tahap ini merupakan tahap komunikasi terjadi dengan adanya keterbukaan secara total. Interaksi yang dilakukan secera spontan tanpa ada rasa takut untuk menyakiti atau menyinggung satu dengan yang lain. Pasangan tidak meminta adanya perpindahan agama. Sikap suportif yang ditunjukan seperti mengijinkan, menjemput saat sedang beribadah di Gereja. Mempercayakan pilihan dari masing-masing agama dan tidak memaksakan kehendak untuk mengikuti agama dari salah satu pihak.
Pasangan ini menunjukan adanya komunikasi yang stabil, saling mendukung saling percaya, ketika ada kesalahpahaman langsung dibicarakan satu dengan yang lainnya. Tidak ada rasa malu untuk saling terbuka satu dengan yang lainnya.

\section{Simpulan}

Melihat hasil temuan dan analisis mengenai topik proses komunikasi interpersonal dalam membangun relasi pasangan beda agama. Dari hasil penelitian ditemukan bahwa aspek dalam proses komunikasi dalam membangun relasi yang dilakukan oleh pasangan beda agama dalam prosesnya ada adaptasi yang terjadi satu dengan yang lainnya dan tidak semata-mata langsung mengenal dekat ada proses didalamnya. Dalam aspek faktorfaktor yang memengaruhi komunikasi interpersonal justru dari lingkungan sekitar dan lingkungan keluarga bukan dari kedua belah pihak pasangan beda agama. Konflik yang dialami juga sebagian besar berasal dari lingkungan keluarga.

Proses komunikasi interpersonal dalam membangun relasi pasangan beda agama diketahui bahwa proses tersebut terjadi dari pengenalan menuju ke hal yang lebih intim. Didalam proses menuju ke yang lebih intim. Komunikasi interpersonal mengalami hambatan-hambatan dan konflik didalam prosesnya. Menguatkan satu dengan yang lain, meyakinkan, dan pemeliharaan hubungan merupakan proses dimana hubungan itu menjadi lebih intim. Pasangan menunjukan adanya komunikasi dua arah yang sangat 
baik, keterbukaan, kenyamanan, sikap percaya, suportif dan mendukung ditunjukan satu dengan yang lainnya. Adanya perbedaan fakta lapangan dengan teori dalam aspek konflik sehingga teori tidak dapat selalu menjelaskan mengenai aspek-aspek apasaja yang terjadi dilapangan.

\section{Daftar Pustaka}

Buku:

Bungin, Burhan. (2013). Metodologi Penelitian Sosial dan Ekonomi: Formatformat Kuantitatif dan Kualitatif untuk Studi Sosiologi, Kebijakan Publik Komunikasi, Manajemen, dan Pemasaran. Jakarta. Kencana Preneda Media Group

Creswell, J.W. (2010). Research Design: Pendekatan Kualitatif, Kuantitatif, dan

Effendy, Onong Uchjana. (2003). Ilmu Teori dan Filsafat Komunikasi. Bandung. Citra Aditya Bhakti.

Iskandar. (2008). Metodologi Pendidikan dan Sosial: Kuantitatif dan kualitatif. Jakarta. Gunung Persada Press

Lukiati, Komala. (2009). Ilmu Komunikasi perspektif, Proses, Dan Konteks. Padjajaran Widya.

Kriyantono, Rachmat. (2006). Teknik Praktis Riset Komunikasi. Jakarta. Kencana

Mulyana, Deddy. (2005). Ilmu Komunikasi Suatu Pengantar. Bandung. PT Remaja Rosdakarya

Papalia, Olds \& Feldman. (2008). Human Development (Perkembangan Manusia). Jakarta. Kencana.
Rakhmat, Jalaludin. (2009). Metode Penelitian Komunikasi. Bandung. PT. Remaja Rosdakarya

Rusli \& Tama, R. (1986).

Perkawinan Antar Agama dan Masalahnya. Bandung : Pionir Jaya

Suranto, Aw. (2011). Komunikasi Interpersonal. Yogyakarta: Graha Ilmu

Turner, L. H., \& West, R. (2008). Teori Komunikasi: Analisis dan Aplikasi. Jakarta. Salemba Humanika.

Turner, L. H., \& West, R. (2009). Understanding Interpersonal Communications: $\quad$ Making Choise in Changing Times. United States. Wadsworth

Winarso, Heru Puji. (2005). Sosiologi Komunikasi Massa. Jakarta : Prestasi Pustaka

Internet :

Primastika, W. (2018). Saat Hubungan Asmara Tak Direstui Orangtua. Diakses pada tanggal 16 Juli 2020 melalui https://tirto.id/saathubungan-asmara-tak-direstuiorangtua-cN3k. Pada Pukul 23.43 WIB. 